\title{
DYNAMICS OF SIBERIAN PALEOLITHIC COMPLEXES (BASED ON ANALYSIS OF RADIOCARBON RECORDS): THE 2012 STATE-OF-THE-ART
}

\author{
Yaroslav V Kuzmin \\ Institute of Geology \& Mineralogy, Siberian Branch of the Russian Academy of Sciences, Novosibirsk 630090, Russia. \\ Email: kuzmin@fulbrightmail.org. \\ Susan G Keates \\ Email: archres2010@t-oniline.de.
}

\begin{abstract}
Our updated database of Siberian Paleolithic radiocarbon records (the 2011 date list of $~ 800$ values) was used to analyze the patterns of population changes, following the methodology developed previously (Kuzmin and Keates 2005). Although the main conclusions remain similar to our 2005 results, some new features were also detected. The intensity of occupation after $\sim 35,000-34,000$ BP was higher than previously thought, and the rise in population began at 20,000-19,000 BP. It is once again confirmed that no significant decline can be observed for the Last Glacial Maximum ( 22,000-16,000 BP). The relationship between climate and Paleolithic humans in Siberia was complex and without a clear trend toward the intensification of occupation during the warm phases.
\end{abstract}

\section{INTRODUCTION}

Large ${ }^{14} \mathrm{C}$ data sets are extensively used for the reconstruction of the population history of prehistoric humans (e.g. Collard et al. 2010; Peros et al. 2010; Steele 2010; Lemmen et al. 2011; BocquetAppel et al. 2012) and animals (e.g. Ugan and Byers 2008; Nikolskiy et al. 2011; MacDonald et al. 2012). A recent overview of this approach can be found in Williams (2012). Due to rapid data accumulation, the need for updating the databases and their interpretation is constant. In this paper, we present the 2012 situation of the ${ }^{14} \mathrm{C}$ records for the Siberian Paleolithic with an analysis of their frequency. Previously, our studies were based on about $440{ }^{14} \mathrm{C}$ values obtained before 2005 (see Kuzmin and Keates 2005; Fiedel and Kuzmin 2007; Fiedel et al. 2007).

\section{MATERIAL AND METHODS}

For the updated analysis, the latest published database (see Kuzmin et al. 2011) was used. It consists of $\sim 800{ }^{14} \mathrm{C}$ values for the late Middle Paleolithic and the Upper Paleolithic complexes in Siberia, totaling 168 sites and site components (see Figure 1). For the geographic subdivision of Siberia, we use primary sources (Suslov 1961; Shahgedanova 2002). The spatial distribution of the ${ }^{14} \mathrm{C}$-dated localities is very uneven: the majority of sites are situated in southern Siberia (south of $55^{\circ} \mathrm{N}$ ), while in the Arctic regions (north of $65^{\circ} \mathrm{N}$ ) there are few Paleolithic ${ }^{14} \mathrm{C}$-dated sites. As for the longitudinal distribution, sites are concentrated in the western and eastern parts of Siberia, between $80^{\circ}$ and $120^{\circ}$ E. As a result, both western Siberia (including the Urals, Figure 1) and eastern Siberia are the best-studied regions (Figure 2); especially noteworthy is eastern Siberia where 39\% of sites by latitude and $70 \%$ of sites by longitude are located.

Before entering the ${ }^{14} \mathrm{C}$ data into the analysis, a critical evaluation of their reliability should be conducted. On the one hand, the criteria used for "chronometric hygiene" (sensu Spriggs 1989:590-8) should be rigorous; examples are research by Kuzmin and Tankersley (1996) and Pettitt et al. (2003). On the other hand, the artificially high requirements can lead to confusing results when most of the ${ }^{14} \mathrm{C}$ dates appear to be of dubious quality as in the case of Graf (2009a); see details in Kuzmin (2009). Therefore, common sense should be employed when examining the quality of the data.

(c) 2013 by the Arizona Board of Regents on behalf of the University of Arizona

Proceedings of the 21st International Radiocarbon Conference edited by A J T Jull \& C Hatté

RADIOCARBON, Vol 55, Nr 2-3, 2013, p 1314-1321 


\section{Y V Kuzmin \& S G Keates}

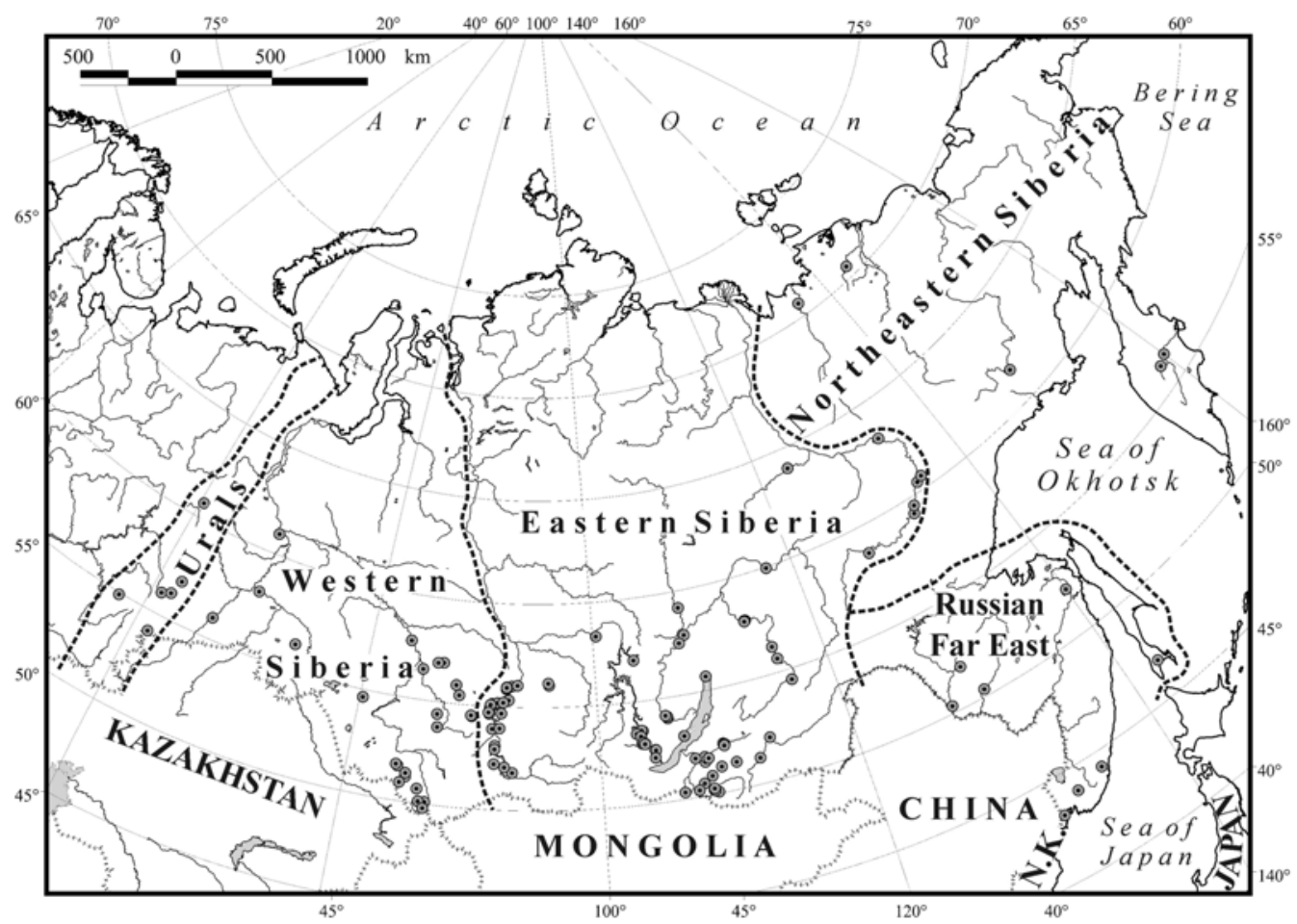

Figure 1 Position of ${ }^{14} \mathrm{C}$-dated Siberian Paleolithic sites (with major geographic regions). N.K. $=$ North Korea.

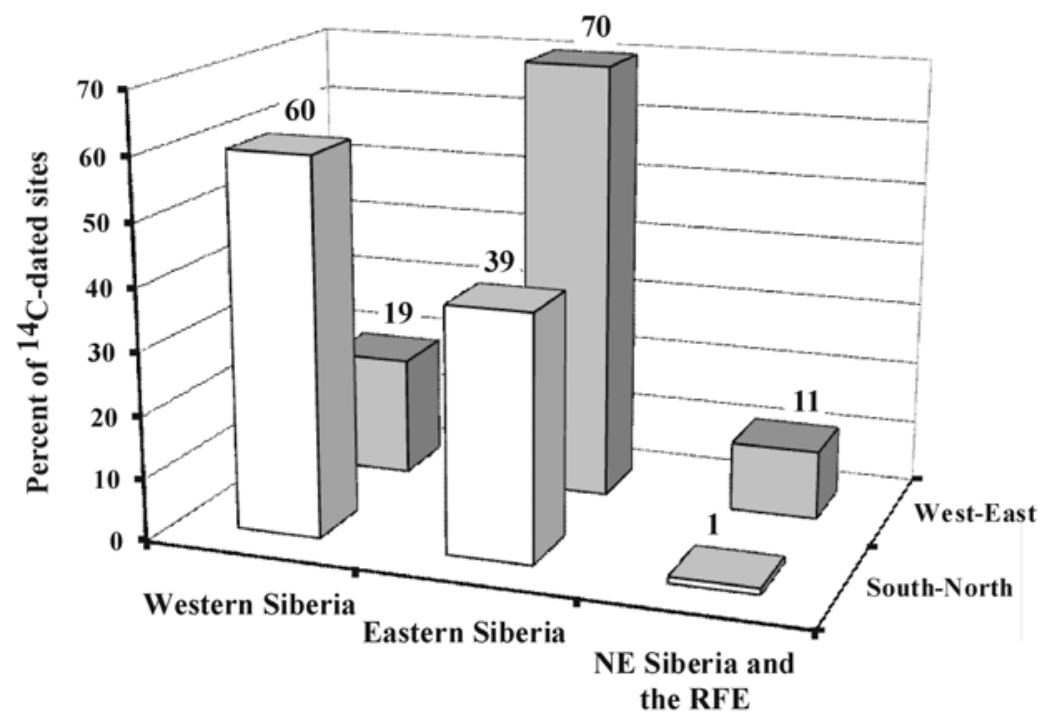

Figure 2 Geographic distribution of ${ }^{14} \mathrm{C}$-dated Siberian Paleolithic sites, in percent values

In this study, there are 4 main criteria for rejecting raw ${ }^{14} \mathrm{C}$ dates: 1$)$ inversions in age-depth profiles; 2) uncertainties of association with cultural components and lack of documentation; 3) association with megafaunal remains from mass accumulations ("mammoth cemeteries"), which are often only 


\section{Dynamics of Siberian Paleolithic Complexes}

very loosely related to human presence; and 4) infinite ages (i.e. greater than). Of the 801 original ${ }^{14} \mathrm{C}$ values from Kuzmin et al. (2011), 56 (7.0\% of the total) are rejected due to stratigraphic inversions; 50 (6.2\%) due to unclear association, including the values derived from the "mammoth cemeteries"; and 43 (5.4\%) as infinite dates. In total, we discarded $149{ }^{14} \mathrm{C}$ dates (18.6\%). As a result, $652{ }^{14} \mathrm{C}$ values (81.4\%) are accepted as reliable and used here for the reconstruction of Paleolithic population dynamics in Siberia. The approach follows Kuzmin and Keates (2005), and occupation episodes were counted for the time span of $\sim 49,000-10,000$ BP (Table 1). We accept the age of $\sim 10,000 \mathrm{BP}$ as the general upper limit for the Paleolithic cultural complexes in Siberia (e.g. Vasil'ev 2003:522).

Concerning the possible distortion of our data set by "taphonomic bias," put forward by Surovell et al. (2009) and caused by decreasing preservation of archaeological sites and paleontological materials as their ages increase, it was shown that it does not affect the reliability of large ${ }^{14} \mathrm{C}$ date series significantly (Peros et al. 2010; Williams 2012). Thus, we consider our data as a reliable and representative source for understanding the changes in Siberian Paleolithic populations at the first degree of approximation.

\section{RESULTS AND DISCUSSION: THE 2012 STATUS}

The updated distribution of occupation episodes for the Siberian Paleolithic is presented in Figure 3. Compared to our previous study (Kuzmin and Keates 2005), several new features can be detected: 1) at $\sim 32,000-21,000 \mathrm{BP}$, the intensity of occupation is higher (average 12.3 episodes per $1000 \mathrm{yr}$ ) than in the 2005 analysis (average value 7.9 per $1000 \mathrm{yr}$ ); 2) the increase in occupation began at $\sim 20,000$ BP compared to $\sim 16,000$ BP detected previously; and 3) no clear decrease in occupation is confirmed for the Last Glacial Maximum (LGM), neither in the narrow ( 20,000-18,000 BP; e.g. CLIMAP 1976) nor broader ( 22,000-16,000 BP; e.g. Clark et al. 2009) sense of the LGM duration (see Figure 3).

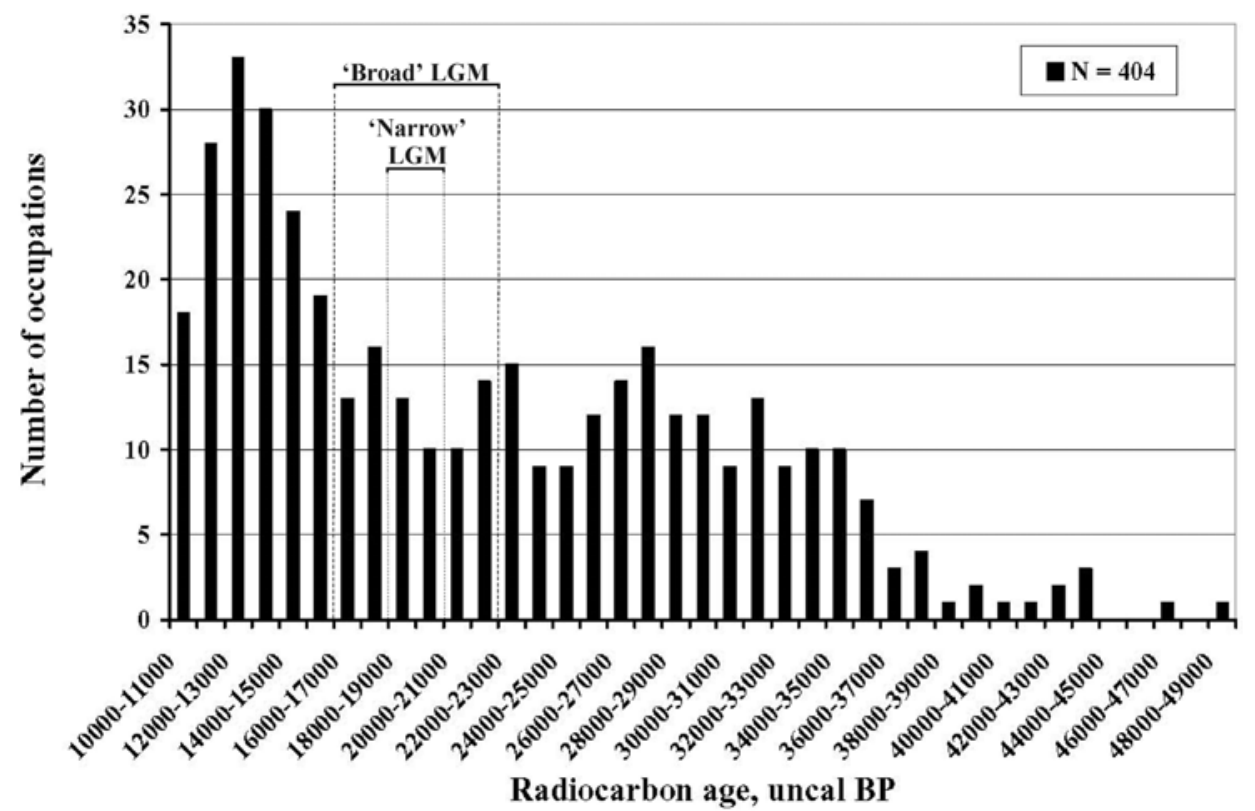

Figure 3 Frequency distribution of occupation episodes for Siberian Paleolithic complexes 


\section{Y V Kuzmin \& S G Keates}

Generally, the intensity of human occupation in southern Siberia after 36,000 BP seems to be higher than previously thought. This is especially true at 32,000-31,000 BP (13 in this study vs. 7 in Kuzmin and Keates 2005) and 28,000-27,000 BP (16 vs. 6). The beginning of the rise of Paleolithic populations in Siberia at the end of the LGM can now be assigned to 20,000 BP, with a minor drop at $17,000-16,000$ BP (Figure 3). These conclusions became possible after incorporating the new ${ }^{14} \mathrm{C}$ values in the database. Compared to our earlier study (Kuzmin and Keates 2005), the amount of material used for this paper has increased by $>50 \%$.

The distribution of raw ${ }^{14} \mathrm{C}$ dates mainly follows frequencies of occupation episodes (Table 1 , Figure 4). However, for some 1000-yr slices, definite artifacts are observed: there is a very high number of ${ }^{14} \mathrm{C}$ dates for $\sim 28,000-27,000 \mathrm{BP}$ (36 values) and $\sim 22,000-21,000 \mathrm{BP}$ (28 values). To a large extent, this is due to numerous ${ }^{14} \mathrm{C}$ dates generated for the Yana RHS (the former) and Malta (the latter) sites, compared to far less ${ }^{14} \mathrm{C}$ dates for the adjacent 1000 -yr timespans. Occupation frequencies for these time periods are 16 and 14, respectively (Table 1, Figures 3-4). It is clear that in order to avoid an artificial increase in the frequencies of ${ }^{14} \mathrm{C}$ dates, normalization of the initial ${ }^{14} \mathrm{C}$ records is necessary, and an occupation episode approach with its advantage over the simple counting of the frequency of ${ }^{14} \mathrm{C}$ dates seems to be feasible (see details in Fiedel and Kuzmin 2007:743-4).

Table 1 Frequencies of ${ }^{14} \mathrm{C}$ dates and occupation episodes for the Siberian Paleolithic (original data after Kuzmin et al. 2011, revised).

\begin{tabular}{lcc}
\hline Time intervals (yr BP) & Number of ${ }^{14} \mathrm{C}$ dates & Number of occupations \\
\hline $10,000-11,000$ & 40 & 18 \\
$11,000-12,000$ & 59 & 28 \\
$12,000-13,000$ & 76 & 33 \\
$13,000-14,000$ & 58 & 30 \\
$14,000-15,000$ & 42 & 24 \\
$15,000-16,000$ & 22 & 19 \\
$16,000-17,000$ & 19 & 13 \\
$17,000-18,000$ & 27 & 16 \\
$18,000-19,000$ & 13 & 13 \\
$19,000-20,000$ & 14 & 10 \\
$20,000-21,000$ & 19 & 10 \\
$21,000-22,000^{\mathrm{a}}$ & 28 & 14 \\
$22,000-23,000$ & 18 & 15 \\
$23,000-24,000$ & 13 & 9 \\
$24,000-25,000$ & 14 & 9 \\
$25,000-26,000$ & 14 & 12 \\
$26,000-27,000$ & 20 & 14 \\
$27,000-28,000^{\mathrm{a}}$ & 36 & 16 \\
$28,000-29,000$ & 19 & 12 \\
$29,000-30,000$ & 13 & 12 \\
$30,000-31,000$ & 11 & 9 \\
$31,000-32,000$ & 15 & 13 \\
$32,000-33,000$ & 9 & 9 \\
$33,000-34,000$ & 14 & 10 \\
$34,000-35,000$ & 11 & 10 \\
$35,000-36,000$ & 7 & 7 \\
$36,000-37,000$ & 4 & 3 \\
$37,000-38,000$ & 4 & 4 \\
$38,000-39,000$ & 1 & 2 \\
$39,000-40,000$ & 2 &
\end{tabular}




\section{Dynamics of Siberian Paleolithic Complexes}

Table 1 Frequencies of ${ }^{14} \mathrm{C}$ dates and occupation episodes for the Siberian Paleolithic (original data after Kuzmin et al. 2011, revised). (Continued)

\begin{tabular}{lcc}
\hline Time intervals (yr BP) & Number of ${ }^{14} \mathrm{C}$ dates & Number of occupations \\
\hline $40,000-41,000$ & 1 & 1 \\
$41,000-42,000$ & 1 & 1 \\
$42,000-43,000$ & 2 & 2 \\
$43,000-44,000$ & 4 & 3 \\
$44,000-45,000$ & 0 & 0 \\
$45,000-46,000$ & 0 & 0 \\
$46,000-47,000$ & 1 & 1 \\
$47,000-48,000$ & 0 & 0 \\
$48,000-49,000$ & 1 & 1 \\
Total & $\mathbf{6 5 2}$ & $\mathbf{4 0 4}$ \\
\hline
\end{tabular}

${ }^{\mathrm{a}}$ For these intervals, multiple ${ }^{14} \mathrm{C}$ dates at some sites distort the occupation picture (see text).

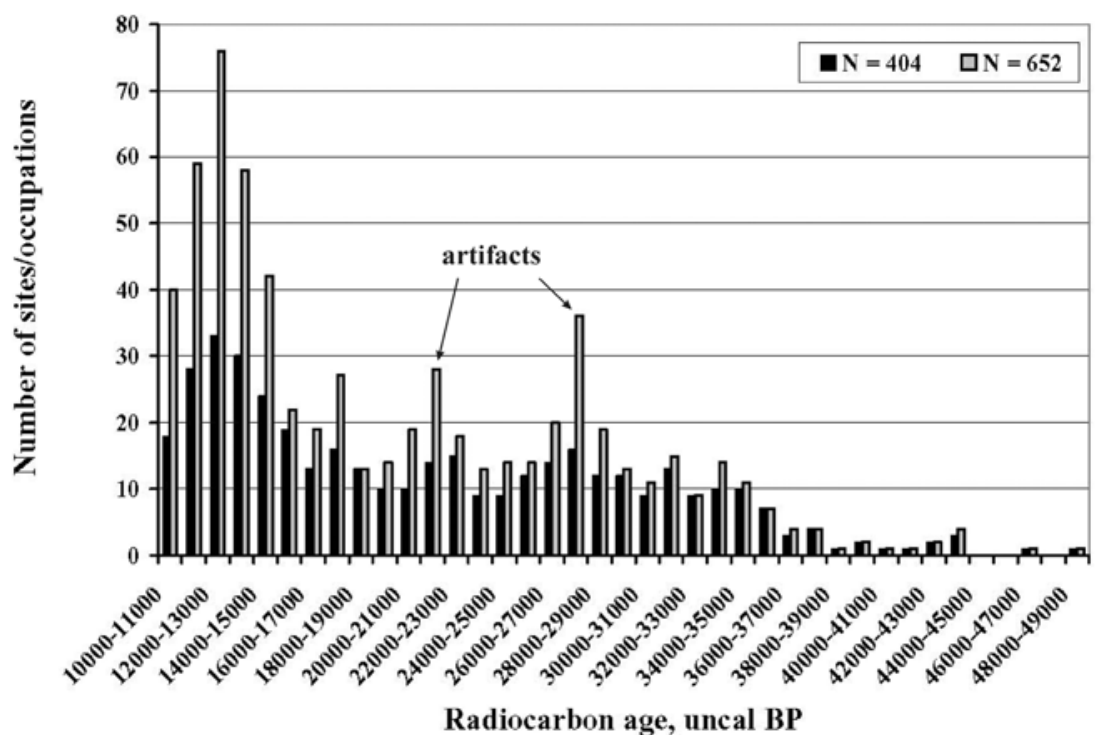

Figure 4 Comparison of frequencies of ${ }^{14} \mathrm{C}$ dates (gray bars) and occupation episodes (black bars) for the Siberian Paleolithic.

An example of what we perceive to be a clear misunderstanding of the occupation episode approach (sensu Kuzmin and Keates 2005) is given in a paper by Goebel et al. (2010). They assumed that the younger ${ }^{14} \mathrm{C}$ values of $\sim 9750$ BP (MAG-637) and $~ 9960$ BP (LE-3024) for Layer 7 of the Ushki 1 site on the Kamchatka Peninsula along with the older dates of $\sim 14,300-13,600$ BP and $~ 11,360$ 10,810 BP should be accepted by those who count the occupation episodes using our approach: “...their [Kuzmin and Keates (2005)] prescribed analytical method of counting 'occupation episodes' requires the use of the full suite of dates” (Goebel et al. 2010:2644). Further, they write: "Following this method, if we consider all of the uncalibrated ${ }^{14} \mathrm{C}$ dates from Ushki-1, layer 7 ... we would conclude that the cultural layer represents five occupation episodes: 9,000-10,000, 10,000$11,000,11,000-12,000,13,000-14,000$, and $14,000-15,000{ }^{14} \mathrm{C}$ BP. The implication of these results would be that layer 7 represents a series of occupations spanning as much as 5000 years" (Goebel et al. 2010:2645). 


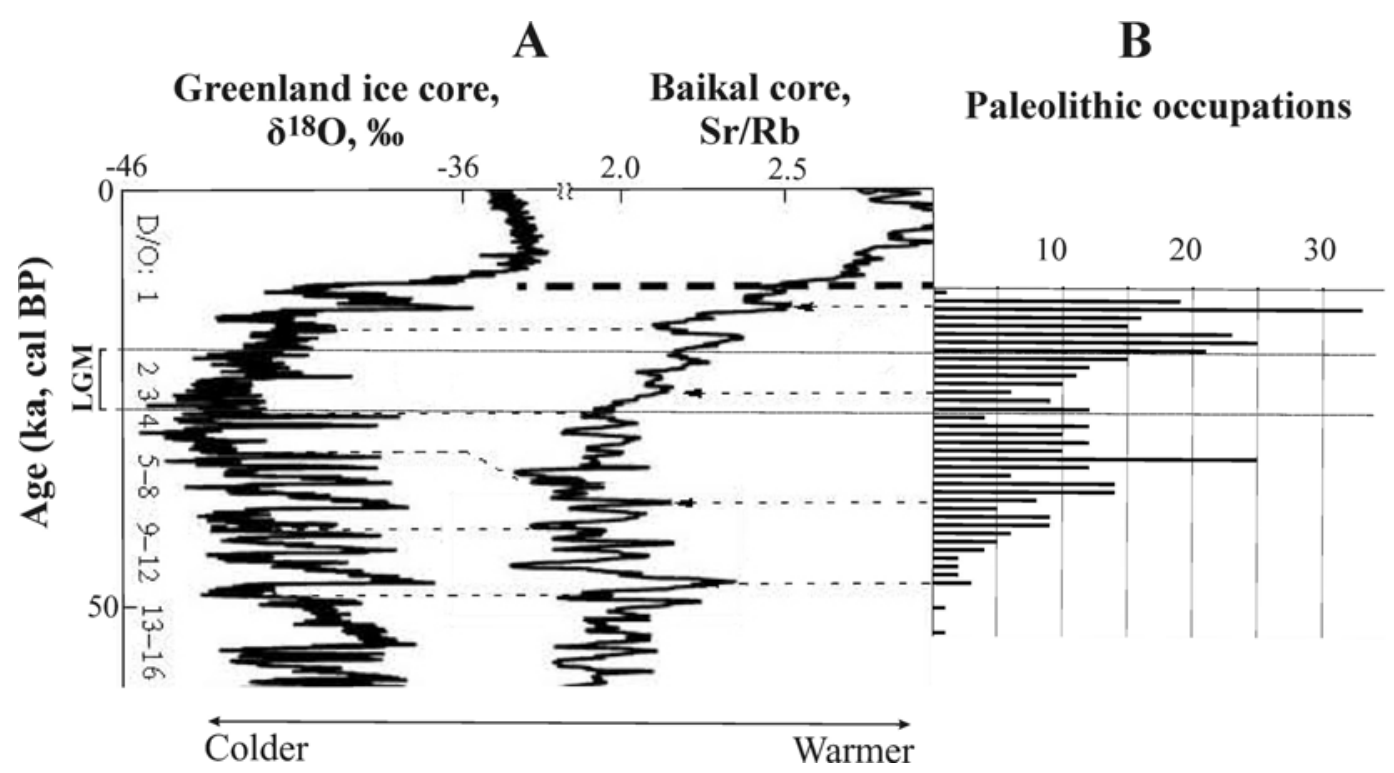

Figure 5 Comparison of climatic fluctuations in the Greenland and Lake Baikal records (A; Goldberg et al. 2008, modified) and intensity of human occupation in Siberia (B; see Figure 3). The numbers on the vertical axis are the DansgaardOeschger (D/O) events for the last 50,000 cal yr.

However, the younger dates of $\sim 9960-9750$ BP for Layer 7 clearly are outliers because of the older age of the overlying Layer 6, 10,800-8790 BP (e.g. Goebel et al. 2010; Kuzmin et al. 2010), and should therefore be rejected (see above). We never stated (e.g. Kuzmin and Keates 2005:777-80) that the "full suite of dates" should be used without prior critical examination.

As for the relationship between Paleolithic humans and Pleistocene megafauna in Siberia, it was recently concluded that the hunting pressure on woolly mammoths and rhinoceroses was relatively weak and did not contribute considerably to their extinction (MacDonald et al. 2012; Stuart and Lister 2012; see also Kuzmin 2010, 2011). Ugan and Byers (2007, 2008), and Nikolskiy et al. (2011) independently arrived at the same conclusion. It is apparent that the sparse human communities of the final Upper Paleolithic ( 15,000-10,000 BP) in northern Siberia were unable to significantly affect the already decreasing mammoth and rhinoceros populations, and that environmental changes were the major factors that led to the final extinction of the megafauna.

In order to compare the frequencies of human occupation for the Siberian Paleolithic with high-resolution paleoclimatic records, it is necessary to calibrate the ${ }^{14} \mathrm{C}$ age for each occupation episode (Table 1). This was done with the help of CALIB 6.1.0 software (Reimer et al. 2009), following the approach by Fiedel and Kuzmin (2007). For comparison of occupation frequencies with climatic oscillations in Siberia at $\sim 53,000-11,000$ cal BP, the geochemical record of the $\mathrm{Sr} / \mathrm{Rb}$ ratio in the Lake Baikal cores as reflecting both global and regional warmings and coolings, was chosen (Figure 5, "Sr/Rb" column). As one can see, no direct correspondence between climatic changes and intensity of human presence can be observed. For example, a steady rise in occupation is typical for $\sim 40,000-30,000$ cal BP, despite several large climatic fluctuations (D/O events 4-8, Figure 5). The peak at $32,000-31,000$ cal BP does not correspond to either a warm (Dansgaard-Oeschger event) or cold (Greenland stadial) interval (see also Fiedel and Kuzmin 2007:747). At the LGM, 26,000$19,000 \mathrm{cal}$ BP, the population size fluctuated but did not decrease (average occupation frequency is 


\section{Dynamics of Siberian Paleolithic Complexes}

10.7 per 1000 yr), with a minimum at $24,000-23,000$ cal BP (6 occupations). The attempt by Graf (2005, 2009b) to "revive" the idea of LGM abandonment of Siberia (e.g. Goebel 2002, 2004) contradicts the primary evidence, and cannot be accepted (see discussion in Kuzmin 2008; Kuzmin and Keates 2005).

\section{CONCLUSION}

The newly acquired data generally confirm our previous conclusions (Kuzmin and Keates 2005). However, some new features can also be observed. The intensity of Paleolithic occupation in Siberia since $~ 35,000-34,000 \mathrm{BP}$ seems to be higher than was previously detected. The increase of population size began at $20,000-19,000 \mathrm{BP}$, several millennia earlier than it was suggested before. Once again, no significant decline is observed for the LGM timespan in Siberia. Therefore, the relationship between climate and Paleolithic humans in Siberia was nonlinear as suggested previously (e.g. Fiedel and Kuzmin 2007).

\section{ACKNOWLEDGMENTS}

We are grateful to several colleagues for assistance in data collection, and to 2 anonymous reviewers for comments. The staff of the NSF-Arizona AMS Laboratory (University of Arizona, Tucson, AZ, USA) was very helpful in providing space and support for our spring 2012 visit and data processing. This study was supported by the Project "GIS Modeling and Spatial Analysis of Environmental Systems and Their Components" of the Siberian Branch of the Russian Academy of Sciences (RAS), Program IV.31.2; Partnership Integrative Project of the Far Eastern and Siberian branches of RAS No. 73; and the Project "Problems of Desertification of Central Asia," RAS Program 4.6.

\section{REFERENCES}

Bocquet-Appel JP, Naji S, Linden MV, Kozlowski J. 2012. Understanding the rates of expansion of the farming system in Europe. Journal of Archaeological Science 39(2):531-46.

Clark PU, Dyke AS, Shakun JD, Carlson AE, Clark J, Wohfarth B, Mitrovica JX, Hostetler SW, McCabe AM. 2009. The Last Glacial Maximum. Science 325(5941):710-4.

CLIMAP Project Members. 1976. The surface of the IceAge Earth. Science 171(4232):1131-7.

Collard M, Buchanan B, Hamilton MJ, O’Brien MJ. 2010. Spatiotemporal dynamics of the Clovis-Folsom transition. Journal of Archaeological Science 37(10): 2513-19.

Fiedel SJ, Kuzmin YV. 2007. Radiocarbon date frequency as an index of intensity of Paleolithic occupation of Siberia: Did humans react predictably to climate oscillations? Radiocarbon 49(2):741-56.

Fiedel SJ, Kuzmin YV, Keates SG. 2007. Siberia in the Late Glacial, ca. 18,000-10,000 RCYBP (20,00012,000 CALYBP): Did climate impact Paleolithic populations? Current Research in the Pleistocene 24: 29-31.

Goebel T. 2002. The "microblade" adaptation and recolonization of Siberia during the late Upper Pleistocene. In: Elston RG, Kuhn SL, editors. Thinking Small: Global Perspectives on Microlithization. Arlington:
American Anthropological Association. p 117-31.

Goebel T. 2004. The search for a Clovis progenitor in sub-Arctic Siberia. In: Madsen DB, editor. Entering America: Northeast Asia and Beringia before the Last Glacial Maximum. Salt Lake City: University of Utah Press. p 311-56.

Goebel T, Slobodin SB, Waters MR. 2010. New dates from Ushki-1, Kamchatka, confirm 13,000-cal-BP age for earliest Paleolithic occupation. Journal of Archaeological Science 37(10):2640-9.

Goldberg EL, Phedorin MA, Chebykin EP, Khlystov OM, Zhuchenko NA. 2008. The decade-resolved record of the response of East Siberia to abrupt climatic changes in the North Atlantic over the last glacial-interglacial cycle. Doklady Earth Sciences 421A(6):961-4.

Graf KE. 2005. Abandonment of the Siberian mammothsteppe during the LGM: evidence from the calibration of ${ }^{14} \mathrm{C}$-dated archaeological occupations. Current Research in the Pleistocene 22:2-5.

Graf KE. 2009a. "The Good, the Bad, and the Ugly": evaluating the radiocarbon chronology of the middle and late Upper Paleolithic in the Enisei River valley, south-central Siberia. Journal of Archaeological Science 36(3):694-707.

Graf KE. 2009b. Modern human colonization of the Siberian mammoth steppe: a view from south-central Si- 


\section{Y V Kuzmin \& S G Keates}

beria. In: Camps M, Chauhan P, editors. Sourcebook of Paleolithic Transitions. New York: Springer. p 479501.

Kuzmin YV. 2008. Siberia at the Last Glacial Maximum: environment and archaeology. Journal of Archaeological Research 16(2):163-221.

Kuzmin YV. 2009. Comments on Graf, Journal of Archaeological Science 36, 2009 “ 'The Good, the Bad, and the Ugly': evaluating the radiocarbon chronology of the middle and late Upper Paleolithic in the Enisei River valley, south-central Siberia." Journal of Archaeological Science 36(12):2730-3.

Kuzmin YV. 2010. The extinction of woolly mammoth (Mammuthus primigenius) and woolly rhinoceros (Coelodonta antiquitatis) in Eurasia: review of chronological and environmental issues. Boreas 39(2): 247-61.

Kuzmin YV. 2011. Mammalian fauna from Palaeolithic sites in the Upper Yenisei River basin (southern Siberia): review of the current zooarchaeological evidence. International Journal of Osteoarchaeology 21(2):218-28.

Kuzmin YV, Keates SG. 2005. Dates are not just data: Paleolithic settlement patterns in Siberia derived from radiocarbon records. American Antiquity 70(4):77389.

Kuzmin YV, Tankersley KB. 1996. The colonization of Eastern Siberia: an evaluation of the Paleolithic age radiocarbon dates. Journal of Archaeological Science 23(4):577-85.

Kuzmin YV, Dikova MA, Cruz RJ. 2010. Radiocarbon age of the Paleolithic layers at Ushki 1 site, Kamchatka (Northeastern Siberia): new dates from the N. N. Dikov excavation in 1989. Current Research in the Pleistocene 27:47-8.

Kuzmin YV, Orlova LA, Zenin VN, Lbova LV, Dementiev VN. 2011. Radiocarbon dating of the Palaeolithic of Siberia and the Russian Far East: materials for ${ }^{14} \mathrm{C}$ data catalogue (as of the end of 2010). Stratum Plus 1: 171-200. In Russian with English abstract.

Lemmen C, Gronenborn D, Wirtz KW. 2011. A simulation of the Neolithic transition in Western Eurasia. Journal of Archaeological Science 38(12):3459-70.

MacDonald GM, Beilman DW, Kuzmin YV, Orlova LA, Kremenetski KV, Shapiro B, Wayne RK, Valkenburgh BV. 2012. Pattern of extinction of the woolly mammoth in Beringia. Nature Communications 3:893, doi: 10.1038/ncomms1881.

Nikolskiy PA, Sulerzhitsky LD, Pitulko VV. 2011. Last straw versus Blitzkrieg overkill: climate-driven changes in the Arctic Siberian mammoth population and the Late Pleistocene extinction problem. Quaternary Science Reviews 30(17-18):2309-28.

Peros MC, Munoz SE, Gajewski K, Viau AE. 2010. Prehistoric demography of North America inferred from radiocarbon data. Journal of Archaeological Science 37(3):656-64.

Pettitt PB, Davies W, Gamble CS, Richards MB. 2003. Palaeolithic radiocarbon chronology: quantifying our confidence beyond two half-lives. Journal of Archaeological Science 30(12):1685-93.

Reimer PJ, Baillie MGL, Bard E, Bayliss A, Beck JW, Blackwell PG, Bronk Ramsey C, Buck CE, Burr GS, Edwards RL, Friedrich M, Grootes PM, Guilderson TP, Hajdas I, Heaton TJ, Hogg AG, Hughen KA, Kaiser KF, Kromer B, McCormac FG, Manning SW, Reimer RW, Richards DA, Southon JR, Talamo S, Turney CSM, van der Plicht J, Weyhenmeyer CE. 2009. IntCal09 and Marine09 radiocarbon age calibration curves, 0-50,000 years cal BP. Radiocarbon 51(4): 1111-50.

Shahgedanova M, editor. 2002. The Physical Geography of Northern Eurasia. New York: Oxford University Press. $571 \mathrm{p}$.

Spriggs M. 1989. The dating of the island Southeast Asian Neolithic: an attempt at chronometric hygiene and linguistic correlation. Antiquity 63(240):587-613.

Steele J. 2010. Radiocarbon dates as data: quantitative strategies for estimating colonization front speeds and event densities. Journal of Archaeological Science 37(8):2017-30.

Stuart AJ, Lister AM. 2012. Extinction chronology of the woolly rhinoceros Coelodonta antiquitatis in the context of late Quaternary megafaunal extinctions in northern Eurasia. Quaternary Science Reviews 51:117.

Surovell TA, Finley JB, Smith GM, Brantingham PJ, Kelly R. 2009. Correcting temporal frequency distributions for taphonomic bias. Journal of Archaeological Science 36(8):1715-24.

Suslov SP. 1961. Physical Geography of Asiatic Russia. San Francisco: W. H. Freeman. 594 p.

Ugan A, Byers D. 2007. Geographic and temporal trends in proboscidean and human radiocarbon histories during the Late Pleistocene. Quaternary Science Reviews 26(25-28):3058-80.

Ugan A, Byers D. 2008. A global perspective on the spatiotemporal pattern of the Late Pleistocene human and woolly mammoth radiocarbon record. Quaternary International 191(1):69-81.

Vasil'ev SA. 2003. Faunal exploitation, subsistence practices and Pleistocene extinctions in Paleolithic Siberia. In: Reumer JWF, de Vos J, Mol D, editors. Advances in Mammoth Research. Rotterdam: Natural History Museum. p 513-56.

Williams AN. 2012. The use of summed radiocarbon probability distributions in archaeology: a review of methods. Journal of Archaeological Science 39(3): 578-89. 